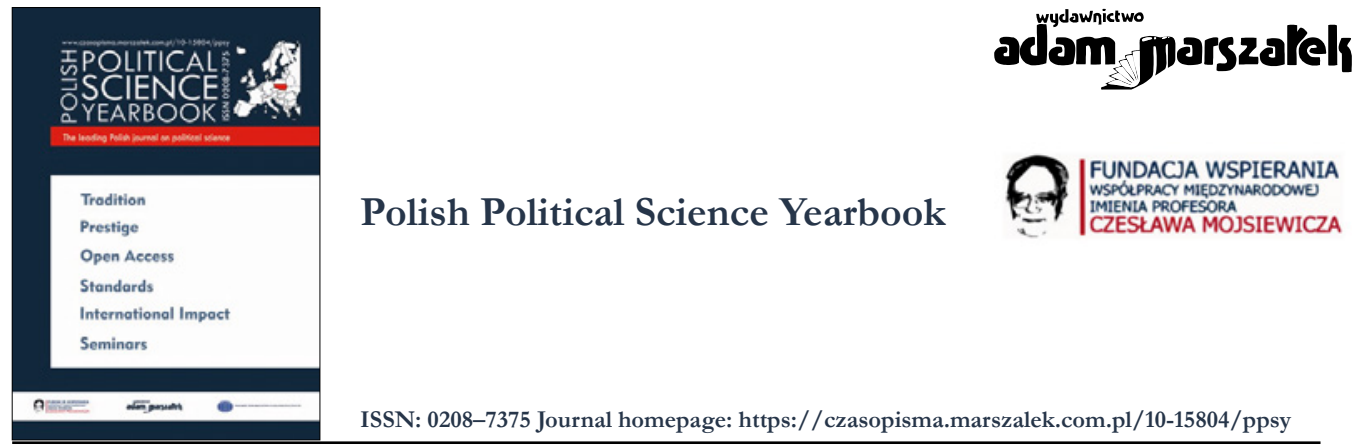

\title{
Poland's Reason of State in the Creation of a New International Order. Foreign Policy as Poland's Reason of State in the 21st Century
}

\section{Piotr Lewandowski}

ORCID: 0000-0002-3664-4815

To cite this article please include the following information:

- Journal title: Polish Political Science Yearbook

- Volume number: 50

- Year of publication: 2021

- Published ahead-of-print

Example styles:

[APA Style]: Lewandowski, P. (2021). Poland's Reason of State in the Creation of a New International Order. Foreign Policy as Poland's Reason of State in the 21st Century. Polish Political Science Yearbook, 50(issue number), pages. https://doi.org/10.15804/ppsy202140

[Chicago Style]: Piotr Lewandowski, "Poland's Reason of State in the Creation of a New International Order. Foreign Policy as Poland's Reason of State in the 21st Century" Polish Political Science Yearbook 50, no. [issue number] (2021).

To link to this article: https://doi.org/10.15804/ppsy202140

Published ahead-of-print

\begin{tabular}{ll}
$\frac{\text { Final submission: }}{\text { Published online: }}$ & 13 July 2021 \\
\hline Printed issue: $\quad 2021$ \\
\hline Submit your article to PPSY
\end{tabular}




\title{
Piotr Lewandowski
}

War Studies University (Poland)

ORCID: 0000-0002-3664-4815

e-mail: p.lewandowski@akademia.mil.pl

\section{Poland's Reason of State in the Creation of a New International Order. Foreign Policy as Poland's Reason of State in the $21^{\text {st }}$ Century}

\begin{abstract}
The article analyzes the Polish reason of state in changing international order understood as the loss of hegemon position by the United States. The author defines the reason of state as an analytical operant and relates it to the security and sovereignty of a state in the international environment. The text also outlines possibilities of development of Poland's reason of state in the region and global geopolitics.
\end{abstract}

Keywords: security, Poland's reason of state, geopolitics, new international order

\section{Introduction}

The changes taking place nowadays in the area of international relations arouse concerns and require standing political observers. There are also certain constant features of states that need to adjust themselves to the variables originating from the environment of international security. Such constants are, for instance, sovereignty and the reason of state. They need permanent adjustment to the prevailing condition, even though they are not susceptible to substantial and rapid changes that sometimes are required by the situation.

This text deals with the issues relating to the Polish reason of state in the transforming environment of international security. The first problem conforming to the assumption relating to the reason of state studies (Swift, 2010) is the implementation of this notion in the conditions of the science of national and international security. Another issue is to define Poland's reason of state in the context of the qualitative change of contemporary international relations determining global and regional security. The main adopted assumption has been the need to work out Poland's reason of state given the changing policies, position, 
and strategy of the United States in the world and the area of the eastern flank of NATO. This text also presumes that recognition of political realism is an appropriate approach to constructing the sectors of implementation of the Polish reason of state in the context of the crisis of the Atlantic option of national and regional security.

The methodology used in the article comes from social sciences and studies on security. Owing to the characteristics of the described phenomena, a turn toward prognostics and heuristic methods has been applied. A considerable part of the study has been based on the scenario method, which is a description of a future possible and probable situation characterizing the researched phenomenon (object, system, process) (Świeboda, 2017) while its aim is to determine the future logical and coherent system of events as a result of proposed decisions (Perycz, 2009). The scenario methodology has been modified and adapted to the analytical features since such a form allows for generating possible policy options in the future and investigating their consequences (Bodio \& Chodubski, 2003). The scenarios have been based on existing (in combination with analyzing relevant literature) and hypothetical information (Świeboda, 2015). Also, the methods of deduction and induction typical of the prognostic approach have been used (Secomski, 1971).

\section{Reason of State - An Attempt to Describe and Define}

The Polish scientific literature on the subject struggles with the problem of defining the reason of state. Ryszard Zięba, Czesław Maj, and Kazimierz Łastawski point out the problems arising because of the multitude of views regarding the reason of state arising from different traditions and more or less successful attempts to transplant this notion from Anglo-Saxon literature onto the Polish soil. The reason of state is not a standalone concept which - as it was indicated - is hard to define. However, this aspect should be looked at from a different angle - as an opportunity provided by this type of phenomenon. For the needs of analysis, for the needs of research, the reason of state may be defined each time differently, keeping in mind individual guidelines that are typical of this notion.

Alongside the assumption of numerous approaches and interdisciplinarity of research, operationalization and conceptualization of the reason of state should refer to the essence of this concept with a need to consider the minimum scope of its meaning. This notion has been devalued by its being used in public discourse, has assumed symbolic and narrational references, and has become a concept of mythical dimensions, which can be placed in ever different sequences of meaningful elements or included in new contexts since they contain a kind of a minimum residuum of meaning that makes it possible to recognize the same signs in different contexts (Howarth, 2008). Therefore, it is worth attempting to determine the minimum elementary scope of meaning of the reason of state, which in analytical contexts may assume a broader form of a research operant.

The basis of reference for understanding the notion of the reason of state is the state and its prerogatives. In the traditional sense, it was the state to which determination of reason 
or interest referred to (Łastawski, 2016). The very notion of the reason of state has been given an enormous number of definitions and has been used to describe diverse situations (Rzegocki, 2008).

With a view to the above postulate for the need to determine the minimum semantic field of the reason of state, it should be defined generally enough to constitute a basis for interdisciplinary approaches and at the same time in sufficient detail to grasp the crux of the matter without introducing additional redundant descriptions and enhancements. The holistic approach to defining the reason of state is needed because of the functioning of this notion in many disciplines of political and administrative, security, historical science, or legal sciences. Precision effects rather from the postulate of the need to understand the reason of state within the same categorization framework.

A broad approach to the reason of state demands that it is referred to the securitization of state existence. Securement is understood as a political process in the form of a mechanism of creating strategies for resolving problems of and threats to state security (Szalacha-Jarmużek, 2013): "securitization itself can be interpreted as a technique or tool of governmental security practices" (Gupta, 2006). It takes place in the following areas of the state security sector: political (which refers to the protection of sovereignty), military - with regard to survival, social - in the protection of identity, economic - for protection and improvement of wellbeing, environmental protection - as protection and building of sustainable development of the state (Musiol, 2018).

The notion of the reason of state may be narrowed down and made more specific through a natural synthesis of political realism and national interest since it is political realism that "transfers the notion of interest defined in the categories of power" (Morgenthau, 2010). Concerning the reason of state and its minimum assumptions, such a category will be power (maximization of opportunities), development, and progress (minimization of threats). In political realism, the latter are more attainable for medium-sized states aspiring toward the category of power, although it should always be the state's goal, also identified by the reason of state.

Equating the reason of state to the category of national interest may be misinterpreted. It is a vital interest of the state that is at stake, which directly in the discourse are frequently identified with the reason of state (Kuźniar, 2006). Not every state's interest shall fit into the category of the reason of state (Kałążna \& Rosicki, 2013), which means that there is a need for the hierarchization of national interests. It shall allow narrowing and broadening the analytical category of the reason of state to match the needs of research and scientific inquiries. Because the categorization of the reason of state was to be the narrowing one, it should be pointed out that these are vital interests of the state, that is, those that refer to its substance: sovereignty, integrity, and society. Protection of those three shall always refer to the notion of the reason of state.

As a result of the above findings, the reason of state shall be defined as securitization of vital interests of the state. Such an approach opens up several research options since 
securitization is a process, a political mechanism, i.e., an empirical, sequential and structured feature. On the other hand, vital interests can be determined, defined, and described in conceptual, quantitative, and qualitative terms. Such an approach to the understanding of the reason of state allows for the determination of the "efforts made in order to minimize threats [securitization] and maximize development opportunities of the state" (Łastawski, 2016).

\section{Theoretical Relations of the Raison d'État, Sovereignty and National Interest in the Context of the Theory of Political Realism}

The disintegration of the bi-polar system caused disorientation of the international situation. Paradoxically, the cold war period guaranteed relative stability. The disorientation of states, especially those that had liberated their sovereign potential, anarchized the international arrangement.

The lack of insight of Polish elites into the international structure resulted in the adoption of the security paradigm based on the alliance with the most powerful pro-democratic country in the world as it was recognized that "the strategic support on the part of another political entity capable of successful action in the case of potential conflicts [...] and special relations either with the United States or the European Union are of fundamental importance for Poland's security". (Furmański, 2007). The adopted prerequisite recognizes the US as the global power it used to be at the end of the $20^{\text {th }}$ century and the hopes pinned on the $\mathrm{EU}$ as a strategic partner and building of common security. Polish thinker professed the myth of the United States as a military power which outdistanced the rest of the world, as Roman Kuźniar wrote: "in 2003, the US military budget will be equal to about $40 \%$ of global defense spending and will exceed the military budget of 14 successive countries (including China and Russia) taken together" (Kuźniar, 2003).

However, that situation did not last long. The end of the $20^{\text {th }}$ and the beginning of the $21^{\text {st }}$ century is a period that Jacek Bartosiak calls a geopolitical pause (Bartosiak, 2018). Although this perspective is not specific enough and is repeatedly used in his work, it indicates that that period was characterized by instability in the transformation of the international order from the bi-polar one, through short-lived unipolarity, to forming the germs of multi-polarity. That period was decisive for Poland's having worked out its reason of state based on accession to the NATO structures under the US leadership.

The problem to be pointed out concerns the direction and strength of Poland's alliance with the US. At the beginning of the $21^{\text {st }}$ century, there were visible symptoms of the decay of US power because of its hegemonic attitude toward the globe as a whole. Samuel Huntington forewarned that as a "benevolent hegemon", the United States will become an object of attacks for other civilizations' forces or political/military blocs (Huntington, 1999). Despite some people's skepticism, the US continued to promote itself as a military power, which was particularly visible in the security strategy adopted at that time. Charles 
Krauthammer affirmed, however, that the US was not only a global military, technological, diplomatic, or cultural power, but that its influence was constantly on the rise (Krauthammer, 2002/2003).

The United States undoubtedly reached the peak of its might at the beginning of the $21^{\text {st }}$ century, right after the pacification of Iraq. Added to this should be the earlier ideological success connected with the defeat of communism, the triumph of liberal democracy (Kissinger, 1994), as well as the pressures exerted on the countries of Central Europe, Africa, Latin America, and Asia to become societies of "free access" and through the introduction of the "Washington consensus" (Stańczyk, 2004) facilitated institutional penetration by international organizations (Ferguson, 2017). Although the US scores much more successes in international politics, its hegemonic failure caused the collapse of the post-cold war order of the world (Brzeziński, 1999; Czornik, 2018).

The US is losing its primary role in the world in several important aspects. The wars in Iraq and Afghanistan exhibited the maximum operational potential of the American army (Okrasa, 2017). The United States faced the dilemma of positioning itself in the new structure, which had pushed regional powers up to the international rank (Miłoszewska, 2009). It was particularly evident after the financial crisis, which had undermined the standing of the US, especially among Western economies. Further neo-imperial activities of Russia, which as a (seemingly) dying power, disclosed the weakness of US diplomacy already during the $2^{\text {nd }}$ war in Chechnya, and even more brutally on the example of Georgia and Ukraine.

Those events, especially the conflict in Ukraine, are ongoing, which means that in the current decade, the world is in the process of forming the poles of empires. The world will not become "normal" as Robert Kagan wants to see it (Kagan, 2009). Sooner, new trends of international dependencies will become crystallized, preceded by periods of unrest and uncertainty or, as John Gaddis said: periods of integration and fragmentation (Gaddis, 1991).

Within the perspective of forming a new system after the end of the post-cold war order, the Polish reason of state should be particularly sensitized to primary issues, such as sovereignty. As note by Bolesław Balcerowicz, the authors of a new international order in Europe are welfare states, which build and expand their networks of dependencies. That will lead to the weakening of attributes of nation-states, especially sovereignty, and egoistically formulated national interest, including the reason of state. It will also translate into the crystallization of a new organizational structure of those states (Balcerowicz, 2005).

Therefore, Poland's reason of state should not focus on the protection of sovereignty. More precisely, transformation into post-sovereignty is a natural and evolutionary phenomenon (perhaps reversible, but it seems that it would require the making of autarchy, that is, utopia). According to Balcerowicz, it should not focus even on the protection of national interests. It is, however, an error resulting from over-confidence in the objectivity and independence of international institutions (Kaczyńska, 2016). Poland's reason of state at the time of shaping a new international order should be a firm elaboration of non-partisan national interests in 
the form of protection of sovereignty (Giddens, 2009), or rather its gradual loss for the highest price possible, in exchange for the greatest benefits for the state rather than for its elites, at the same time recognizing that the loss of sovereignty is an evolutionary phenomenon in line with the contemporary dimension of international relations and security.

The United States gradually give way to the emerging powers, especially China. The model of "defensive" imperialism they promulgate in the material, institutional or legal dimension may prove insufficient on the international scale (Cooper, 2003). Moreover, a conflict with Germany and a collision course vis-à-vis the entire EU may germinate many threats concerning hard power control and the existent well-shaped American soft power in Europe. As a US advocate in the old continent, a would-be intermediary between Russia, the EU, and the US, Poland needs to find a new task to raise its rank and gain broader international significance.

Added to this is also the process of reversal of political polarity in the US. Donald Trump's policies were visibly oriented toward Asia. Its military and economic attention are focused on Chinese and Middle East activities (Strategiczny, 2019). It is an evident threat to Poland since the attention of the US, "at present the most important political and military ally of Poland, moves to Asia. It directly affects Poland's security" (Sykulski, 2018).

A realistic approach is needed for the determination of the Polish reason of state. The decay of the hitherto international order, creating a new unipolar, networked, and globalized one, as has been described, requires substantial political and intellectual involvement of nation-states. It is nowadays, in the era of globalization, in the times when post-sovereignty and extraterritoriality are prophesized, that the fundamental features of states are exceptionally needed. States continued to constitute a fundamental component of international political relations (Łoś-Nowak, 2013), and it seems not to change in the forthcoming future, although non-state actors ever more intensively affect changes in this respect and determine the ultimate quality of regional or bilateral relations of states (Gruszko, 2013). The reason of state in contemporary relations should be its adjustment to new challenges. Since the times of the Peace of Westphalia, states have been evolving, and this capability to introduce changes and adapt oneself to diverse external conditions (organic vision of the state) seems to suggest that it is sensitivity to certain variables and insensitivity to others will be decisive for the longest possible existence of a sovereign state.

In its substantial categories, the state should fulfill itself through earlier mentioned political realism. Seeking a place for oneself in the international structure through tasks and dependencies proves insufficient. The range of possibilities of contemporary medium-sized states has been substantially limited by the primacy of organizations and institutionalization of international order. That is why a realistic and cool-headed insight into the state of affairs should not be rejected. It is necessary to continue the autonomous and necessary state policy based on political realism with the doctrinal liberal democratic ideology (Kissinger, 2016).

In the classical thought of Hans Morgenthau, political realism assumes the need to treat the states and behaviors in international order as typically societal activities characterized 
by human deficiencies. However, most important for Poland is to utilize the geographical principles. Morgenthau directly says that political realism in international relations is based on geography, which determines the possible and probable foreign policy goals (Morgenthau, 2010). Two more dimensions are added to the geographical characteristics of the state: transnational (Dumala, 2012) and cybernetic (Lakomy, 2015).

A combination of political realism with critical geopolitics may materialize since it "defined the role of geography in the political theory of strategy, is a theory of spatial linkages" (Mondry, 2000). It is not, however, a sufficient approach, since it is necessary to "take into account the aspect of deterritorialization of the world and the fact that today a large part of the social and political activity takes place in the transnational area as well as in cyberspace and is relatively detached from a specific territorial location" (Potulski, 2010). That is why the classical concepts of empires and powers need to be redefined.

A contribution of the concept of political realism to geopolitical research and analysis may be "the transfer of the notion of interest defined in the categories of power" (Morgenthau, 2010 ) to the area of political and international activities. Hence geopolitics, analytics, and prognostics are of special importance in constructing realistic national interests defined by the reason of state. Therefore, the comments prescribe expansion of the intellectual base in Poland, equipped with suitable analytical tools, which would be capable of building apolitical scenarios and models of international developments. Its extent should not be geographically restricted due to the globalization of international relations (one may speak about cybernetic spatiality) (O'Tuathail, 1998) and the continuous growth of interrelations between states from beyond civilizational and cultural regions.

Political realism is firmly based on geographical determinism. The context of globalization of international relations, the deterritorialization of states, and the emergence of cyberspace as a socio-political platform of network relationships requires a different than classical look at a state's reason of state from the viewpoint of political realism. Political realism directly reveals that extreme inequality of state prevails in international reality (O'Tuathail, 1998). Likewise, in the network international order, organizational and corporate structures absorb or control other smaller regional branches. The same goes for cyberspace, which appears as a primacy of equality and freedom. In contrast, in reality, it upholds the division between the center and the peripheries, where the "centers are sources generating new values, attitudes, and behaviors, while the peripheries are usually recipients of models and values coming from the centers" (Potulski, 2010).

Poland's reason of state perceived from the viewpoint of the above and deriving from political realism is to recognize its status of a medium-sized state, appreciate it, and "work out a political order which will take it into account" (Morgenthau, 2010). That political order involves a strategy of state security and a strategy of its internal development, as a result of which the resources and means can be distributed and transformed into international profits. It is where the need to retain sovereignty in the strategic sectors of the state, such as energy, critical infrastructure, or information and media security, proves to be necessary. 
Both concepts of sovereignty and raison d'etat have been redefined under conditions of globalization and the interdependence of states. The reason of state of medium-sized states, developing states, understood in the categories of national interest, is in the interest of states perceived as powers. States that orient their reason of state toward protecting national interest behave in line with the expectations of imperial states, which in this way - endangering vital interest - divert attention from what is fundamental, namely sovereignty. "Alongside expansion of state structures, the reason of state started to be associated with the elementary rules of the functioning of the state" (Łastawski, 2016), and the destruction of state structures marked the beginning of particularization of the reason of state and its detachment from the need to protect sovereignty. Transnational economic and political phenomena facilitate the eternal field of the rivalry of world powers, namely elimination of nation-states and their replacement by "larger entities of a different nature, which will better harmonize with technical and moral requirement of the contemporary world" (Morgenthau, 2010).

As a developed state (Dołaczyliśmy, 2019), having accepted its international position, having counted its forces and means, Poland can realize itself in the categories of power within the global system, gaining a "due international status" understood as a "set of bilateral and multilateral relations with other states" (Kaczyński, 2011). It is a realistic approach to the reason of state understood in the categories of interest (which in the medieval and modern realities would be perceived rather as an homage) through the loss of Bodinian sovereignty to preserve certain spatial and administrative prerogatives. However, the primacy of the reason of state and interest over sovereignty makes states determined to reintegrate into post-sovereignty perceived and reduced to the suitability of choice (Kaczmarski, 2015). Therefore, as long as the state is free to choose, independent, and sovereign, its sovereignty is not threatened, contrary to the reason of state and national interest.

\section{Polish Reason of State - Its State and Prospects}

It is extremely difficult to define the Polish reason of state in the perspective of political realism and geopolitics. The first basic difficulty is posed by analyzing the geopolitical situation in the region and worldwide - and it should be the initial one. To a certain extent, this need is fulfilled by power-metric indicators, though they cannot be translated into real activities of a state but only help realize the specific regional or global averages. The underlying data are far from what has been expected and rather serve the purposes of objectification. Another difficulty involves analyzing the international relationships of a country, its dependencies, and obligations vis-à-vis the international network of states, organizations, and institutions.

It is worth looking at the Polish reason of state in this respect with a view to the crisis in the Atlantic option caused by a change in the international arena, i.e., devaluation of the US position in the world. Poland's status in US politics has recently changed. So far, 
Poland and the plan of building the missile defense shield were treated as an object of American-Russian gameplay (Kiwerska, 2015). The United States itself has abandoned the policy of post-Kissingerian ideology in favor of pragmatism toward changes in the structure of international dependencies. The struggle against terrorism has consumed the forces and means of the US, and the Russian neo-imperial policy in Europe suits it since it pushes the European countries (as the US elites wish to see it) into a stronger alliance with America as a common civilizational and cultural circle (Laruelle, 2012).

Apart from the hitherto comments relating to a strategic partnership, ever more frequently, the issues of cooperation and mutual benefits in the contacts with Washington are raised: "A strategic partnership with the United States is a huge value. With a view of the military and political witness of the European Union, Washington's guarantees are the sole possibility of ensuring security for such countries as Poland. However, this should not be tantamount to waving the struggle for national interests. It is our tenacity, determination, and courage that will decide to what extent we shall benefit from the American partnership" (Pacuła, 2008). The alliance with the US is not and should not be the sole solution as it restricts the spectrum of Polish international efforts and at the same time deprives Poland of the possibility to exert pressure on the American side, thus building an asymmetric web of interdependencies. That is why it is necessary to have a sober approach to this type of assessment and realize own interests, especially in national security.

Poland's reason of state is a strategic partnership with the US, but it should be made clear that neither the alliance is permanent nor the reason of state is unchangeable. All this is because Poland is treated as an object of international gameplay by its Western partners (Grosse, 2016). A change in the perception of Poland in the $21^{\text {st }}$ century consists in abandoning the politics of the ideological struggle of the end of the $20^{\text {th }}$ century in favor of the pragmatic economic policy conducted by the US vis-à-vis all of its partners. A partnership with the US gives us "strategic political rather than economic benefits" (Pacuła, 2008). The United States is a country which is involved in financial draining through companies and corporation which are of a definitely national or even nationalistic character since the financial circles "draw a considerable part of their profits from imperialist exploitation exercised over the rest of the world" (Bidet \& Dumenil, 2011; Klein, 2017) as well as political protection of the global empire. The very creation of the illusion of a world power draws other states into the alliance, in exchange for which the US demands cooperation (which in consequence boils down to strong correlations of its capital with the capital of nation-states).

Polish reason of state in the last decade of the $20^{\text {th }}$ century was determined by the Atlantic option of national and international security. At present, to change this option appears impossible or difficult, and it seems to be an eventuality in the case of a strong crisis of NATO structures. However, there are all indications that this crisis already takes place due to the dwindling role of the United States in the world. Polish reason of state at the beginning of the $21^{\text {st }}$ century should be at present the working out of different strategies of national security, an alternative to the Atlantic option, since the existence of NATO in no 
event "does relieve the Polish state of the obligation to make efforts to maintain the armed forces at the level sufficient to defend its territory" (Kaczyński, 2011).

The deepening of the crisis could be an alternative path of the development of Poland's national security. Such an option could trigger the domino effect among the developing countries, especially from the region of Central and Eastern Europe, which would be against the US interests, especially in the context of its rivalry with China. Nevertheless, security strategies in the event of a crisis of Euro-Atlantic structures should be constantly on the table and even slowly realized as an alternative and potential counterweight to dwindle American domination in the world. That is why Poland's reason of state should be to work out such a status in which, owing to its geopolitical location as a transit and bridging country, the Polish state becomes a junction (in the web structure) connecting the globalized system of regional security with the Atlantic option.

In practice, this would mean a return to the concept of national security, promoting the emergence of a regional security structure with Poland as the leader. Such structures would be characterized by political duality: they would constitute an alternative to the Euro-Atlantic option and pressure the US as the NATO leader. This concept has, in a way, passed the test as NATO-bis (Jureńczyk, 2015). At present, it may be emphasized as a Three Seas Initiative understood as enhancing Poland's activity in regional and international relations (Sienkiewicz, 2016). It is worth reminding that initially, that concept was based on the $16+1$ format, where China was to be a strategic partner and patron of the whole scheme: "A general goal of the $16+1$ collaboration format is first of all consolidation of economic relations with China and working out solutions that would contribute to the development of investment and growth of trade among partners". (Bochenek, 2020). However, Poland changed its geopolitical orientation again toward the Atlantic option, and a subsequent Three Seas summit was held under the patronage of Donald Trump. The situation as a whole could be played much better, not resting only on American promises and assurances but real assistance programmes.

The Three Seas Initiative and a project of military security are, in a way, correct assumptions. The Three Seas Initiative should constitute Polish reason of state, non-partisan, implemented systemically and by stages. The Initiative provides an opportunity for building a platform of regional security in the economic, energy, social, and cultural dimensions. It is the first stage that offers the greatest opportunities for success that were first put forward at the beginning of the 1990s - the ideas for constructing a security bloc in Central and Eastern Europe (Karkoszka, 1994). Differences in political interests of Central and Eastern European countries have been put aside in the new concept, and programmes in which every state sees benefits rather than ill intentions are implemented. It may be the key to paving a plane for reaching political (as in the case of the Visegrád Group) and then military understanding by those states.

Polish reason of state should be characterized not only by pragmatism and political realism but also pro-defense ideology. Securitization of individual sectors, beginning with infrastructure, economy, ecology, energy to the community, and pro-defense policy, should 
be supplemented with supranational efforts authenticating the legitimacy of action and show evident benefits. Ideologizing international relations helps liberate what the Polish state was involved in centuries ago: cultural soft power. The geopolitical situation seems to be exceptionally favorable for it (Siudak, 2020).

The Three Seas Initiative offers opportunities and threats (Ukielski, 2016), though from the geostrategic point of view seems rather ambivalent. On the one hand, it constitutes a rejection of the Three Seas concept proposed by Jerzy Giedroyć as ULB (Ukraine, Lithuania, Belarus). From the geopolitical point of view, this field should be considered lost in the rivalry with Russian neo-imperialism. The war against Ukraine and plans to incorporate Belarus are examples indicating that Russia slowly but determinedly and by stated returns to geopolitics in the form of a territorial empire. Poland may try to weaken Russian influences solely by offering examples and symbolic political actions, that is, act ideologically and pragmatically at the same time.

The situation is different regarding the Three Seas Initiative, where the countries of Central Europe are mostly out of touch with the former empire. New opportunities crop up, for example, Poland's acting as an umpire with regard to numerous conflicts between states in this territory, operating its soft power (culture, democracy, the rule of law, example of economic development) and hard power (alliance with the US, own military force). However, it is not the reason of state to incite conflicts and antagonize states to build alliances and coalitions with the select few. The strength of the Three Seas Initiative will be the minimization of conflicts and the attainment of unanimity in operating own autonomous collaboration programmes.

In the networked and ever more polarized system of international relations, the Polish reason of state is to produce such political, military, social, economic, energy, and military linkages which will constitute a platform of cooperation and regional security in Central Europe. Poland's location as a transit and bridging country, as Polish geo-politicians would like to see it, is not a sufficient determinant to achieve success in the form of getting a status of the peg. It is an error to assume that the "key to the development of the Polish center of strength becomes not the building of own geopolitical bloc but rather geo-economic policy oriented toward development of the country as an economic peg" (Sykulski, 2018). It is supposedly going to happen in cooperation with China. However, close cooperation with China under the New Silk Road initiative is but a dream. It is stated in the report of the Centre for Security Studies indicating that Poland does not take advantage of its position, does not participate in a trade that crosses its territory (Iwanek, 2017). Apart from this, it may be noted after Jacek Bartosiak (2018) the "current level of the movement of goods by railway may be handled by eight additional large ships annually. From this it follows that in order to be a geopolitical factor, traffic along the New Silk Road must be greater, more frequent, faster". Besides, Poland's economic structure nowadays reminds the structure of a neo-colonial country (Romaniszyn, 2016), making building sovereignty even more difficult and explains why Poland is treated as a transit country. 
Another alternative could be to build a strategy based on the concept of perpetual neutrality. However, given its proximity to Russia, Poland cannot achieve the military capability to ensure a sufficient level of defense and deterrence on its own, which does not change the fact that Poland, as a 'frontline' state, should have an adequately numerous and well-equipped army, which must, however, be integrated into Euro-Atlantic structures in the best possible way.

It is impossible to achieve neutrality because of geography and geopolitics. Under the present condition, it would mean that Poland would have to get guarantees from European powers: Germany, France, Russian, and Britain, as well as the United States. However, such a combination seems abstract. Bolesław Balcerowicz notes that neutrality of medium-sized states such as Poland requires international guarantees of powers and a second mandatory condition: the strategy of determwelfent (Kopeć \& Mazur, 2017), which entails having such force which would discourage potential aggressors (Balcerowicz, 2010). It seems, however, that meeting that second condition only, possession of nuclear weapons (Waltz, 1990), could prove exceptionally positive for Poland: the United States would be forced to consolidate its role in the strategic partnership, while Poland would be perceived among the countries of Central and Eastern Europe as sufficiently credible to build around itself an axis of regional security.

\section{Conclusions and Recommendations}

The notion of the reason of state proposed in this study in the form of securitization of vital interests of the state allows for supplementing the definitional operant with a set of measurable characteristics, features, and verifiable facts that may be investigated under the conditions of both national and international security. In case of the reason of state in the situation of globalization and contemporary changes, most important seems to be the loss of confidence in the US as the hegemon of the international order. It entails an immediate threat to security and requires modification of the reason of state into a state security operant (securitization) through maintaining military security and thus sovereignty.

At the same time, there exist real needs to work out alternatives for international development and recognize the US as one of the poles of international order. Such a situation requires deliberate getting rid of the prerogatives of sovereignty in favor of state security in the international environment. It should be accepted that Poland, if a peripheral country in international geopolitics and opportunities, should be verified from this perspective with the simultaneous and continued striving at increasing the might of the state in the region. It seems that the Three Seas or B9 format offers real opportunities for turning Poland into a regional leader, though they require forces and means which the Polish state does not have (Lewandowski, 2019). The change of status and attainment of structural might (e.g., concerning military security) could raise the level of confidence of the countries of the region toward Poland. 


\section{References:}

Balcerowicz, B. (2005). Teorie. koncepcje wojny (i pokoju) po zimnej wojnie. In R. Kuźniar (Ed.), Porządek międzynarodowy u progu XXI wieku. Warszawa.

Balcerowicz, B. (2010). Sity zbrojne w stanie pokoju. kryzysu i wojny. Warszawa.

Bartosiak, J. (2018). Rzeczpospolita między lądem a morzem. O wojnie i pokoju. Warszawa.

Bidet, J., \& Dumenil, G. (2011). Alter-marksizm. Inny marksizm dla innego świata. Warszawa.

Bochenek, R. (2020). Statement for the Polish Press Agency. Wspótpraca regionalna $z$ Łotwą $i$ Serbia oraz zacieśnienie relacji gospodarczych $z$ Chinami. Premier Szydło rozmawiała $w$ Rydze z premierami innych państw. wPolityce. https://wpolityce.pl/swiat/314317-wspolpraca-regionalna-z-lotwa-i-serbia-orazzaciesnienie-relacji-gospodarczych-z-chinami-premier-szydlo-rozmawiala-w-rydze-z-premieramiinnych-panstw

Bodio, T., \& Chodubski, A. (2003). Politologia jako futurologia. In Metafory polityki. Warszawa.

Brzeziński, Z. (1999). Bezład. Polityka światowa u progu XXI wieku. Warszawa.

Cooper, R. (2003). The Breaking of Nations - Order and Chaos in the Twenty-First Century. London.

Czornik, K. (2018). Ewolucja pozycji międzynarodowej USA w okresie pozimnowojennym. Studia Politicae Universitatis Silesiensis, 21.

Dołaczyliśmy do elitarnego grona. Polska krajem rozwiniętym. (2020). https://www.money.pl/gospodarka/ wiadomosci/artykul/dolaczylismy-do-elitarnego-grona-polska.23.0.2416663.html

Dumała, H. (2012). Transnarodowe sieci terytorialne w Europie. Lublin.

Ferguson, N. (2017). Wielka degeneracja. Jak psuja się instytucje i umierają gospodarki. Kraków.

Furmański, P. (2007). Trzecia Rzeczpospolita między Stanami Zjednoczonymi Ameryki a Unią Europejską wybór opcji geopolitycznej. In W. Paruch, \& K. Trembicka (Eds.), Niepodległość. Zależność. Suwerenność. Problematyka zagraniczna w najnowszej polskiej myśli politycznej. Lublin.

Gaddis, J.L. (1991). Toward the Post-Cold World. Foreign Affairs, 2.

Giddens, A. (2009). Europa w epoce globalnej. Warszawa.

Grosse, T.G. (2016). Tragedia państw peryferyjnych. czyli o geopolitycznych dylematach Polski w Unii Europejskiej. In T. Zarycki (Ed.), Polska jako peryferie. Warszawa.

Gruszko, K. (2013). Rola organizacji międzynarodowych w kreowaniu globalnego ładu międzynarodowego.

In E. Haliżak, \& M. Pietraś (Eds.), Poziomy analizy stosunków międzynarodowych. Warszawa.

Gupta, K. (2006). The State of Securitization Theory: A Review of The Politics of Insecurity. In J. Huysmans

(Ed.), The Politics of Insecurity: Fear. Migration and Asylum in the EU. London.

Howarth, D. (2008). Dyskurs. Warszawa.

Huntington, S. (1999). The Lonely Superpower. Foreign Affairs, 2.

Iwanek, K. (2017). Chiński projekt “Nowego Jedwabnego Szlaku”. Retoryka a rzeczywistość. Raport Ośrodka Badań Azji Centrum Badań nad Bezpieczeństwem Akademii Sztuki Wojennej. Warszawa.

Jureńczyk, Ł. (2015). Zewnętrzne i wewnętrzne determinanty opcji atlantyckiej w polskiej polityce zagranicznej i bezpieczeństwa lat dziewięćdziesiątych XX w. In T. Ambroziak (Ed.), Solidarność a demokracja. 25 lat transformacji postkomunistycznej. Toruń.

Kaczmarski, M. (2015). Realizm neoklasyczny. In R. Zięba (Ed.), Teorie i podejścia badawcze w nauce o stosunkach międzynarodowych. Warszawa.

Kaczyńska, D. (2016). Kapitał ma narodowość. Polscy gracze przechodza do ofensywy. Warszawa.

Kaczyński, J. (2011). Polska racja stanu. In B. Jusiak (Ed.), Racja stanu. Poznań

Kagan, R. (2009). Powrót historii i koniec marzeń. Poznań. 
Kałążna, K., \& Rosicki, R. (2013). O interesie narodowym i racji stanu - rozważania teoretyczne. Przegląd Politologiczny, 1.

Karkoszka, A. (1994). Droga Polski do NATO. In M. Kern Jędrychowska (Ed.), Bezpieczeństwo Polski w zmieniajacej się Europie. Toruń.

Kissinger, H. (1994). Dyplomacja. Warszawa.

Kissinger, H. (2016). Porządek światowy. Wołowiec.

Kiwerska, J. (2015). Światowe przywództwo Ameryki w XXI w. Poznań.

Klein, N. (2017). Doktryna szoku. Jak współczesny kapitalizm wykorzystuje klęski żywiołowe i kryzysy społeczne. Warszawa.

Kopeć, R., \& Mazur, P. (2017). Odstraszanie militarne w XXI wieku. Polska - NATO - Rosja. Kraków.

Krauthammer, C. (2002/2003). The Unipolar Moment Revisited - United States World Dominance. The National Interest, 70.

Kuźniar, R. (2003). Niebezpieczeństwo nowego paradygmatu bezpieczeństwa. In R. Kuźniar, \& Z. Lachowski (Eds.), Bezpieczeństwo międzynarodowe czasu przemian. Zagrożenia - Koncepcje - Instytucje. Warszawa 2003.

Kuźniar, R. (2006). Bezpieczeństwo w stosunkach międzynarodowych. In E. Haliżak, \& R. Kuźniar (Eds.), Stosunki międzynarodowe. Geneza. struktura. dynamika. Warszawa.

Lakomy, M. (2015). Cyberprzestrzeń jako nowy wymiar rywalizacji i wspótpracy państw. Katowice.

Laruelle, M. (2012). Russian Euroasianism An Ideology of Empire. Baltimore.

Lewandowski, P. (2019). Geopolityczne idee wielkoprzestrzenne jako soft power - analiza przypadku Rzeczypospolitej. Kwartalnik Bellona, 3.

Łastawski, K. (2016). Dylematy współczesnej polskiej racji stanu. In R. Zięba, \& T. Pawłuszko (Eds.), Polityka zagraniczna Polski w zmieniajacym się ładzie międzynarodowym: wybrane problemy. Kielce.

Łoś-Nowak, T. (2013). Państwowy poziom analizy w stosunkach międzynarodowych. In E. Haliżak, \& M. Pietraś (Eds.), Poziomy analizy stosunków międzynarodowych. Warszawa.

Miłoszewska, D. (2009). Nowy Porządek Świata jako polityczna forma globalizacji. Geopolityka: biuletyn naukowo-analityczny Instytutu Geopolityki, 1(2).

Mondry, J. (2000). Wczoraj. dziś i jutro geopolityki. In J. Mondry (Ed.), W objęciach geopolityki: Polska. Japonia. Eurazja: Publicystyka na łamach "Kultury". London.

Morgenthau, H. (2010). Polityka między narodami. Walka o potęgę i pokój. Warszawa.

Musioł, M. (2018). Znaczenie sekurytyzacji i sektorów bezpieczeństwa w ramach krytycznych studiów nad bezpieczeństwem. Historia i Polityka, 23(30).

O’Tuathail, G. (1998). Postmodern geopolitics? The modern geopolitical imagination and beyond. In G. O’Tuathail, \& S. Dalby (Eds.), Rethinking geopolitics. Londyn.

Okrasa, T. (2017). Ewolucja unipolarnego systemu międzynarodowego i jej implikacje dla bezpieczeństwa międzynarodowego. In K. Czornik, \& M. Szynol (Eds.), Wyzwania i zagrożenia dla bezpieczeństwa międzynarodowego i narodowego pod koniec drugiej dekady XXI wieku. Katowice.

Pacuła, P. (2008). Polska-USA: co może nam dać partnerstwo z Waszyngtonem? Bezpieczeństwo Narodowe, $1-2$.

Perycz, E. (2009). Strategiczne prognozowanie. modelowanie i symulacja. Warszawa.

Potulski, J. (2010). Geopolityka w świecie ponowoczesnym. Częstochowa.

Romaniszyn, K. (2016). Kolonializm w dobie globalizacji? Świat i Słowo, 27.

Rzegocki, A. (2008). Racja stanu a polska tradycja myślenia o polityce. Kraków.

Secomski, K. (1971). Prognostyka. Warszawa. 
Sienkiewicz, M. (2016). Koncepcja Trójmorza w polityce zagranicznej polski po 2015 r. Dyplomacja i Bezpieczeństwo, 1(4).

Siudak, M. (2017). Trójmorze - projekt polski czy chorwacki? http://geopolityka.net/michal-siudaktrojmorze-projekt-polski-czy-chorwacki/

Siudak, M. (2020). Trójmorze.http://geopolityka.net/michal-siudak-trojmorze/

Stańczyk, Z.J. (2004). Konsensus waszyngtoński a reformy w krajach postkomunistycznych. Zeszyty Naukowe, 2.

Strategiczny zwrot Pentagonu. Chiny w centrum uwagi. (2019). https://forsal.pl/artykuly/1390088. strategiczny-zwrot-pentagonu-chiny-w-centrum uwagi.html?fbclid=IwAR0zmZ4dFKd_VzzXIVmIfNL7dK4cg8gUEYYwn4QIm06RzcDA8YPTzLR2FG0

Swift, Cf.A. (2010). Wprowadzenie do filozofii politycznej. Kraków.

Sykulski, L. (2018). Geopolityka a bezpieczeństwo Polski. Warszawa.

Szalacha-Jarmużek, J. (2013). Instrumentarium globalnego panowania. O podmiotowych aspektach globalizacji. Poznań.

Śliwiński, B. (2020). Trójmorze - koncepcja geopolityczna dla każdego. http://geopolityka.net/bartoszsliwinski-trojmorze-koncepcja-geopolityczna-dla-kazdego

Świeboda, H. (2017). Prognozowanie zagrożeń bezpieczeństwa narodowego Rzeczypospolitej Polskiej. Warszawa.

Świeboda, H. (2015). Prognozowanie scenariuszowe w analizie systemowej. In P. Sienkiewicz, H. Świeboda, and E. Szczepaniuk (Eds.), Nie-bezpieczny świat. Systemy. Informacja. Bezpieczeństwo. Warszawa.

Ukielski, P. (2016). Mapa Trójmorza. Przegląd punktów wspólnych i rozbieżności w polityce 12 państw regionu. Raport, 3 .

Waltz, K.N. (1990). Nuclear Myths and Political Realities. The American Political Science Review, 84(3). 